\title{
H2AJ wt Allele
}

National Cancer Institute

\section{Source}

National Cancer Institute. H2A/wt Allele. NCI Thesaurus. Code C162817.

Human H2AJ wild-type allele is located in the vicinity of $12 \mathrm{p} 12.3$ and is approximately $4 \mathrm{~kb}$ in length. This allele, which encodes histone H2A.J protein, is involved in nucleosomal structure. 